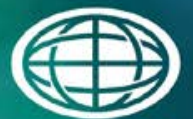

Savannah River

National Laboratory ${ }^{m}$

OPERATED BY SAVANNAH RIVER NUCLEAR SOLUTIONS

\title{
Interpretation of At-Line Spectra from AFS-2 Batch \#3 Ferrous Sulfamate
}

Treatment

E. A. Kyser, P. E. O'Rourke

December 2013

SRNL-STI-2013-00694, Revision 0 
SRNL-STI-2013-00694

Revision 0

\section{DISCLAIMER}

This work was prepared under an agreement with and funded by the U.S. Government. Neither the U.S. Government or its employees, nor any of its contractors, subcontractors or their employees, makes any express or implied:

1. warranty or assumes any legal liability for the accuracy, completeness, or for the use or results of such use of any information, product, or process disclosed; or

2. representation that such use or results of such use would not infringe privately owned rights; or

3. endorsement or recommendation of any specifically identified commercial product, process, or service.

Any views and opinions of authors expressed in this work do not necessarily state or reflect those of the United States Government, or its contractors, or subcontractors.

\section{Printed in the United States of America \\ Prepared for U.S. Department of Energy}


Keywords: $H$-Canyon , $\mathrm{HB}$-Line, $\mathrm{Pu}$ Valence, $M O X, A F S-2, P u(V I)$,

Spectroscopy

Retention: Permanent

\title{
Interpretation of At-Line Spectra from AFS-2 Batch \#3 Ferrous Sulfamate Treatment
}

\author{
E. A. Kyser \\ P. E. O’Rourke
}

December 2013

Prepared for the U.S. Department of Energy under 


\section{REVIEWS AND APPROVALS}

\section{AUTHORS:}

Original approved by E. A. Kyser on 12/10/2013

E. A. Kyser, SRNL, Separations and Actinide Science Programs

Original approved byPatrick O'Rourke on 12/10/2013

P. E. O'Rourke, SRNL, Analytical Development

Date

TECHNICAL REVIEW:

Original approved by T. C. Shehee on 12/10/2013

T. C. Shehee, SRNL, Separations and Actinide Science Programs, Reviewed per E7 2.60 Date

\section{APPROVAL:}

Original approved by T. B. Brown on 12/10/2013

T. B. Brown, Manager

Date

SRNL, Separations and Actinide Science Programs

Original approved by Sharon L. Marra on 12/12/2013

S.L. Marra, Manager

Date

Environmental \& Chemical Process Technology Research Programs

Original approved by S. L. Hudlow on 12/16/2013

S. L. Hudlow, Manager

Date

H-Canyon Process Engineering Manager 


\section{TABLE OF CONTENTS}

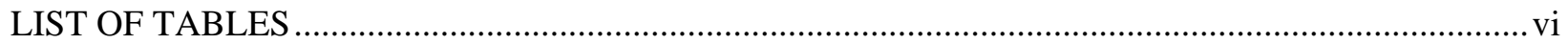

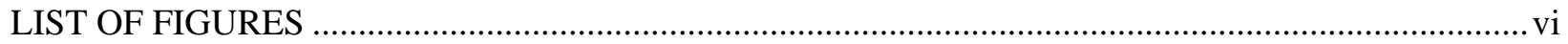

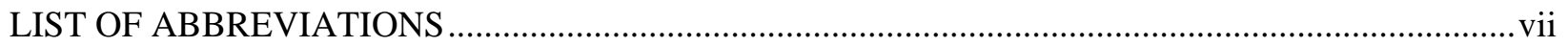

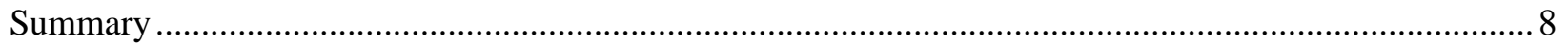

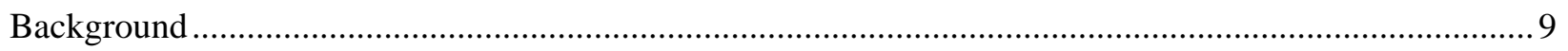

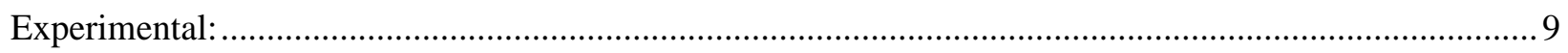

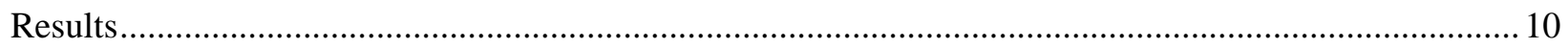

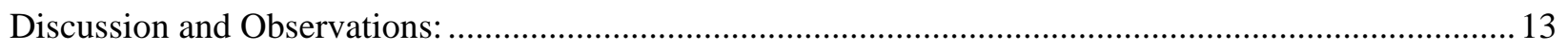

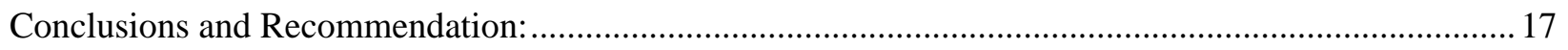




\section{LIST OF TABLES}

Table 1. Analytical Results and Volume History for Batch 3 (7HD Pu-3)...

\section{LIST OF FIGURES}

Figure 1. Conversion of the $\mathrm{Pu}(\mathrm{VI})$ to $\mathrm{Pu}(\mathrm{IV})$ in Tank 12.2 with FS.

Figure 2. Continued Addition of FS Converts Pu(IV) to Pu(III) in Tank 12.2. ................... 11

Figure 3. Pu(III) Mostly Oxidizes Back to Pu(IV) (within few minutes).

Figure 4. Selected Spectra showing time scale of changes from $\mathrm{Pu}(\mathrm{VI})$ to $\mathrm{Pu}(\mathrm{IV})$

to $\mathrm{Pu}(\mathrm{III})$ back to mostly $\mathrm{Pu}(\mathrm{IV})$.

Figure 5. $\mathrm{Pu}(\mathrm{VI}), \mathrm{Pu}(\mathrm{IV})$ and $\mathrm{Pu}(\mathrm{III})$ Speciation during FS Adjustment of

AFS-2 Batch 3 in Tank 12.2 on 9/18/13.

Figure 6. Shift in Main Pu(IV) Absorbance Peak:

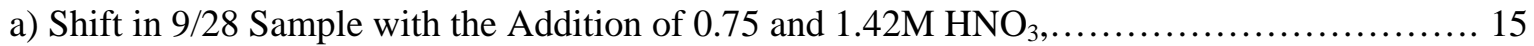

b) Comparison of Batch 2 and Batch 3 at Different Stages and Acid Concentrations. 15

Figure 7. Effect of $\mathrm{HNO}_{3}$ Concentration on the Absorbance Spectrum of $\mathrm{Pu}(\mathrm{IV})$ between 5 and $10 \mathrm{M} \mathrm{HNO}_{3}$. 16

Figure 8. Shift in Main Pu(IV) Absorbance Peak between 1 and $13 \mathrm{M} \mathrm{HNO}_{3}$. 16 


\section{LIST OF ABBREVIATIONS}

$\begin{array}{ll}\text { AFS-2 } & \text { Alternate Feedstock \#2 } \\ \text { ANL } & \text { Argonne National Laboratory } \\ \text { FS } & \text { Ferrous Sulfamate } \\ \text { Kernal } & \text { Integration limits of Gaussian function used to smooth the raw data } \\ \text { PCR } & \text { Principle Component Regression } \\ \text { Sigma } & \text { Parameter which represents the peak half-width of the Gaussian function } \\ & \text { used to smooth the raw data } \\ \text { SRNL } & \text { Savannah River National Laboratory }\end{array}$


SRNL-STI-2013-00694

Revision 0

\title{
Interpretation of At-Line Spectra from AFS-2 Ferrous Sulfamate Batch \#3 Treatment
}

\author{
E. A. Kyser \\ P. E. O’Rourke
}

December 2013

\section{Summary}

Spectra from the "at-line" spectrometer were obtained during the ferrous sulfamate (FS) valence adjustment step of AFS-2 Batch \#3 on 9/18/2013. These spectra were analyzed by mathematical principal component regression (PCR) techniques to evaluate the effectiveness of this treatment. Despite the complications from $\mathrm{Pu}(\mathrm{IV})$, we conclude that all $\mathrm{Pu}(\mathrm{VI})$ was consumed during the FS treatment, and that by the end of the treatment, about $85 \%$ was as $\mathrm{Pu}(\mathrm{IV})$ and about $15 \%$ was as $\mathrm{Pu}(\mathrm{III})$. Due to the concerns about the "odd" shape of the Pu(IV) peak and the possibility of this behavior being observed in the future, a follow-up sample was sent to SRNL to investigate this further. Analysis of this sample confirmed the previous results and concluded that it "odd" shape was due to an intermediate acid concentration. Since the spectral evidence shows complete reduction of $\mathrm{Pu}(\mathrm{VI})$ we conclude that it is appropriate to proceed with processing of this the batch of feed solution for HB-Line including the complexation of the fluoride with aluminum nitrate. 


\section{Background}

Previously, samples from the initial three dissolution batches of AFS-2 feedstock were collected and sent to SRNL for investigation of the valence state of the Pu. Different volumes of ferrous sulfamate (FS) were recommended for each of the batches to reduce the $\mathrm{Pu}(\mathrm{VI})$ to $\mathrm{Pu}(\mathrm{IV})$ based on lab titrations ${ }^{1,2}$. The third batch has been treated with FS in Tank 12.2 while being monitored with an "at-line" spectrometer system and the spectra have been evaluated to determine the success of that treatment.

FS reduces $\mathrm{Pu}(\mathrm{VI})$ to $\mathrm{Pu}(\mathrm{V}), \mathrm{Pu}(\mathrm{V})$ to $\mathrm{Pu}(\mathrm{IV})$ and $\mathrm{Pu}(\mathrm{IV})$ to $\mathrm{Pu}(\mathrm{III})$ stepwise. Each molecule of FS provides one electron for reduction. The reduction of $\mathrm{Pu}(\mathrm{VI})$ to $\mathrm{Pu}(\mathrm{IV})$ requires two moles of FS per mole of $\mathrm{Pu}(\mathrm{VI}) . \mathrm{Pu}(\mathrm{V})$ is generally not very stable in $\mathrm{HNO}_{3}$ solutions and is not readily detected via UVvis spectroscopy. $\mathrm{Pu}(\mathrm{V})$ also would not be recovered by the anion exchange process. Campbell ${ }^{3}$ reports that no $\mathrm{Pu}(\mathrm{III})$ is produced until all the $\mathrm{Pu}(\mathrm{VI})$ has been reduced in $4 \mathrm{M} \mathrm{HNO}_{3}$, and this is assumed to be true for a wide range of high $\mathrm{HNO}_{3}$ concentrations. Therefore, the reduction of $\mathrm{Pu}(\mathrm{VI})$ to $\mathrm{Pu}(\mathrm{IV})$ by the addition of FS will be determined by the elimination of $\mathrm{Pu}(\mathrm{VI})$ from the spectrum and the ingrowth of the $\mathrm{Pu}(\mathrm{IV})$ peaks and will be assumed complete when the $\mathrm{Pu}(\mathrm{III})$ peaks begins to appear. In $7 \mathrm{M}$ or greater concentrations of $\mathrm{HNO}_{3}, \mathrm{Pu}(\mathrm{III})$ is not stable and is oxidized to $\mathrm{Pu}(\mathrm{IV})$ over the course of hours to a few days unless a large excess of reductant is maintained. This memo documents our evaluation of the spectra taken from the "at-line" instrument during the FS treatment in Tank 12.2 and the 9/28/2013 sample of 12.2 that was sent to SRNL for confirmatory measurements.

\section{Experimental:}

H-Canyon Tank Work: The sampler for Tank 12.2 is fitted with an experimental degasser and optical absorbance cell designed by Argonne National Laboratory (ANL). The optical cell is attached by fiber optic cables to an Avantes spectrophotometer and light source, model numbers AvaSpec-2048-USB2VA-50 and AvaLight-DH-S, located in the in the H-Canyon control room. The spectrophotometer is controlled by laptop computer running software written by ANL. This system is referred to as the "atline” spectrometer system throughout this document.

At 10:42 am on September 18, 2013, the sampler and spectrophotometer were switched on and allowed to collect data at approximately 6.5 second intervals for $\sim 28 \mathrm{~min}$. FS was added to Tank 12.2 at approximately 10:49 am followed by a water flush at 10:54 am with the adjustment declared complete by 11:01 am. Real-time absorbance data from the ANL spectrometer showed a decrease in Pu(VI) signal and an increase in $\mathrm{Pu}(\mathrm{IV})$ signal, followed by a decrease in the $\mathrm{Pu}(\mathrm{IV})$ signal and the appearance of $\mathrm{Pu}(\mathrm{III})$.

The post-treatment sample sent to SRNL for spectroscopic comparison was handled similar to previous samples ${ }^{1,2,4}$. A pair of fiber optic lines previously installed through the ceiling of the glovebox allowed a light signal to be brought into the glovebox, passed through the cuvette (containing either a reference solution or a sample), and carried out of the glovebox back to an Avantes spectrometer controlled by a computer $^{5}$. Reference and measurement spectra were taken on the same pair of NIR grade fibers. Light

\footnotetext{
${ }^{1}$ E.A. Kyser, "Reduction of Pu(VI) in Anion Exchange Feedstock for AFS-2 Batches 1 and 2”, SRNL-L3100-2013-00051, Rev. 0, Savannah River National Laboratory, Aiken SC, April 18, 2013.

${ }^{2}$ E.A. Kyser, "Reduction of Pu(VI) in Anion Exchange Feedstock for AFS-2 Batch 3", SRNL-L3100-2013-00161, Rev. 0, Savannah River National Laboratory, Aiken SC, August 28, 2013.

${ }^{3}$ M. H. Campbell, "Selective Reduction of Plutonium(VI) to Plutonium(IV) in a Plutonium(IV-VI) Nitric Acid Solution”, HW68003, Hanford Atomic Products Operation, Richard WA, February, 1961.

${ }^{4}$ E.A. Kyser, P. E. O’Rourke, "Sample Results from the Treatment of Tank 12.2 with FS for Pu(VI) Reduction”, SRNL-L31002013-00127, Rev. 0, Savannah River National Laboratory, Aiken SC, July 24, 2013.

${ }^{5}$ Spectrometer: Thermo-Electric Cooled Fiber Optic Spectrometer, 75 mm Avabench, 2048 pixel TE cooled and regulated CCD detector, with a >150 nm Deep UV detector coating, $25 \mu \mathrm{m}$ slit size, sorting coating with 350 and $590 \mathrm{~nm}$ longpass filter for UA
} 
references were taken prior to the beginning of the experiment and stored. Samples were measured on this system in disposable cuvettes.

\section{Results}

The "at-line" spectra taken on the ANL spectrometer were sent to SRNL for analysis. Trace color in all plots is an indicator of time with blue indicating early time, progressing through green and finally to red. The Pu(VI) signal between 800 and $845 \mathrm{~nm}$ decreases as the FS reductant is consumed and the $\mathrm{Pu}(\mathrm{IV})$ signals at 489, 535, 606, 645 and $743 \mathrm{~nm}$ increase. The spectrum baseline increases during this time which complicates quantitative interpretation.

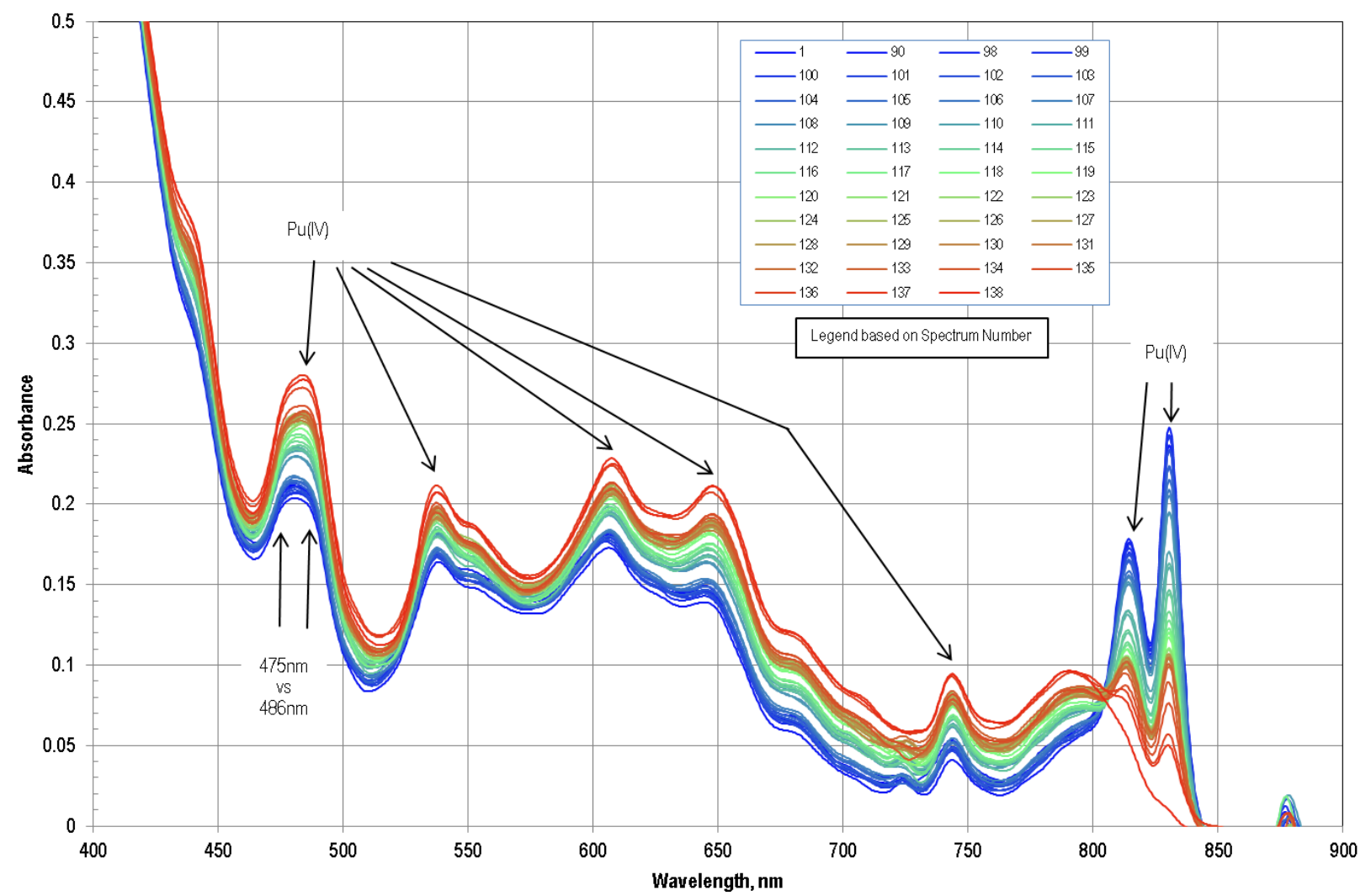

Figure 1. Conversion of the $\mathrm{Pu}(\mathrm{VI})$ to $\mathrm{Pu}(\mathrm{IV})$ in Tank 12.2 with FS.

Figure 1 shows the conversion of $\mathrm{Pu}(\mathrm{VI})$ to $\mathrm{Pu}(\mathrm{IV})$ (previously measured as $39 \%$ of the total $\mathrm{Pu}$ ). The bulk of the change occurred between spectrum \#100 to \#138. At this point, all the Pu(VI) (@811 and $829 \mathrm{~nm}$ ) appears to have been reduced to Pu(IV) (@486 nm). The shape and character of the Pu(IV) looks "odd" in that it is not a sharp peak like was observed in the sample of this solution when it was sampled in the 6.1D dissolver. ${ }^{2}$ As shown in Figure 2, continued addition of FS converts Pu(IV) to $\mathrm{Pu}(\mathrm{III})$ (peaks @560 and $600 \mathrm{~nm}$ ) between spectrum \#138 to 160. During this short time, the Pu(IV) peak nearly disappears. However Figure 3 shows most of this Pu(III) was transient as it rapidly oxidized back to $\mathrm{Pu}(\mathrm{IV})$ between spectrum \#160 and 200. Although Pu(III) should convert back to Pu(IV), it is thought that the oxidation reaction takes several days to occur. As a result, it is hypothesized that large amount of $\mathrm{Pu}(\mathrm{III})$ that is observed in the spectra for a short time is likely a transient sampling or mixing phenomena rather than reflecting the overall conditions in the tank. Insufficient FS was added to convert such a large percentage of the total $\mathrm{Pu}$ to $\mathrm{Pu}(\mathrm{III})$ and if it had been converted it would have taken hours to days to

grating, wavelength range 200-1,100 nm using a USB2 high speed interface to a laptop computer operating Windows XP and Microsoft Excel 2003 or later. 


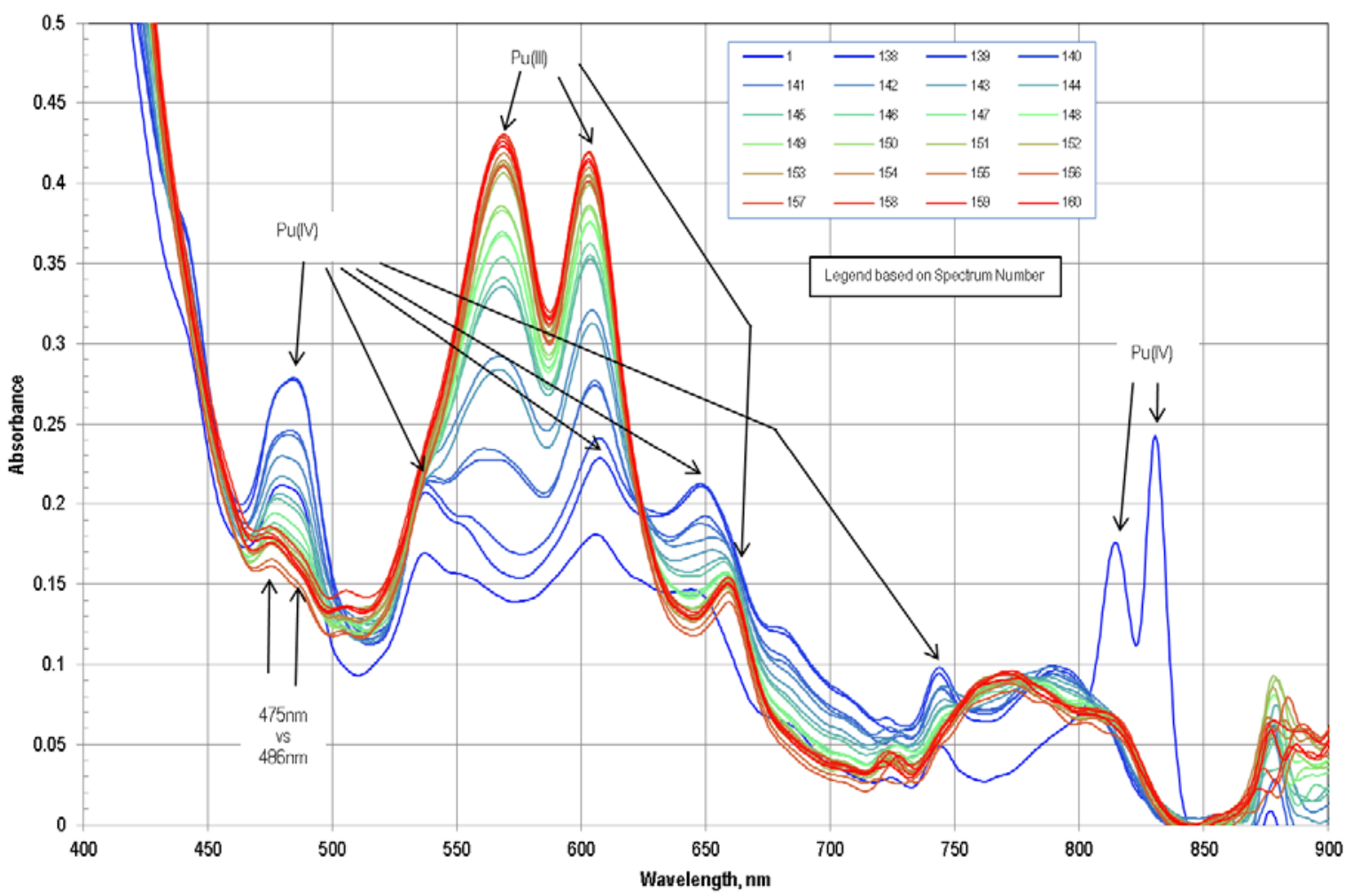

Figure 2. Continued Addition of FS Converts Pu(IV) to Pu(III) in Tank 12.2.

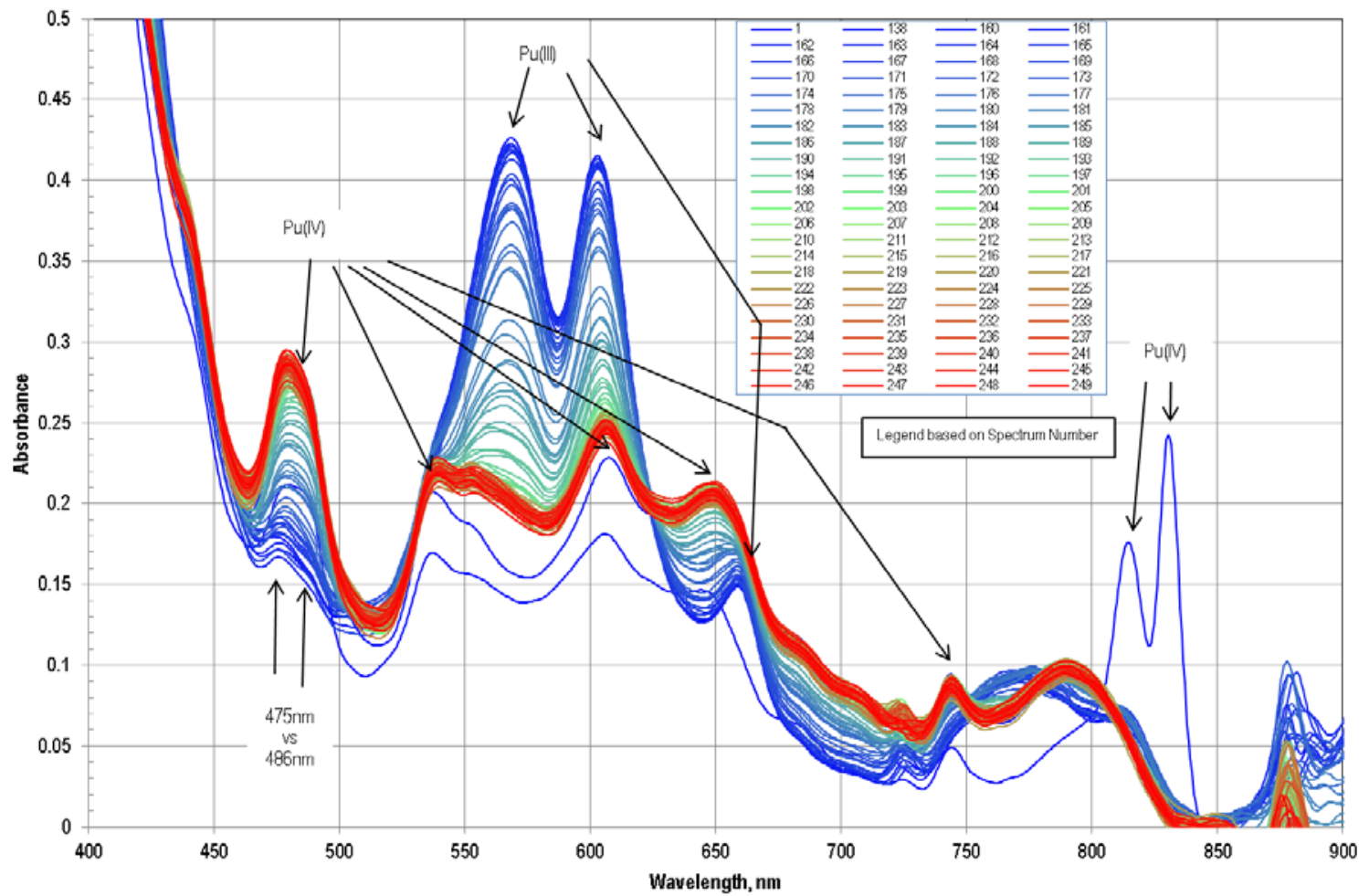

Figure 3. Pu(III) mostly Oxidizes Back to Pu(IV) (within few minutes). 


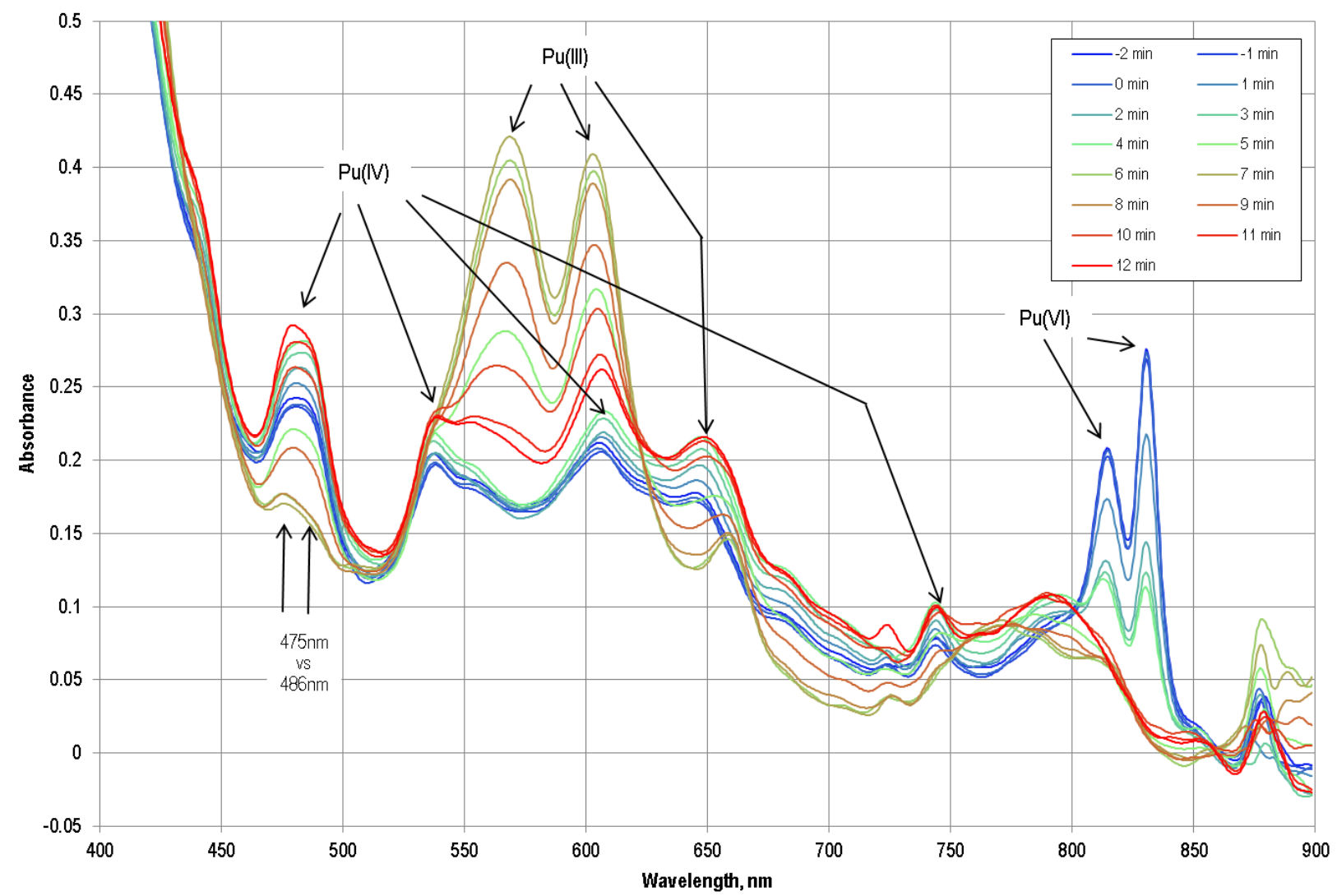

Figure 4. Selected Spectra showing time scale of changes from $\mathrm{Pu}(\mathrm{VI})$ to $\mathrm{Pu}(\mathrm{IV})$ to $\mathrm{Pu}(\mathrm{III})$ back to mostly Pu(IV).

oxidize without the addition of a separate oxidant. It should be recognized final state of the tank solution is the important information and transient behavior may have little long term value.

In order to assess the outcome of the FS addition, it is useful to determine the percentage of $\mathrm{Pu}(\mathrm{VI})$ remaining after completion of reaction. The absorbance data was post-processed at SRNL to extract $\mathrm{Pu}(\mathrm{IV})$ and $\mathrm{Pu}(\mathrm{VI})$ concentration ratios. Absorbance data was read into the Excel spreadsheet program and processed using macro programs from the file PCR_Macros_New_B.xlsm. The macros were written at SRNL for the processing and analysis of absorbance spectral data. Data was processed using a second derivative Gaussian filter to eliminate baseline effects and reduce noise. Typically the filtered data uses parameters sigma $=5$ and $\operatorname{kernel}(\mathrm{k}=$ the integration limits on the Gaussian fitting function $)=50$.

The processed data was analyzed using PCR. The PCR method analyzes data by using weighted averages of spectra in a data set to describe the maximum amount of signal variance. PCR analysis of this data showed three significant components. To simplify the interpretation of the data, the set was divided into two parts, the first consisting of spectra showing the conversion of $\mathrm{Pu}(\mathrm{VI})$ to $\mathrm{Pu}(\mathrm{IV})$, and the second part consisting of spectra showing the interconversion between $\mathrm{Pu}(\mathrm{IV})$ and $\mathrm{Pu}(\mathrm{III})$. PC's for $\mathrm{Pu}(\mathrm{VI})$ and $\mathrm{Pu}(\mathrm{IV})$ are derived from the first portion of the data set. A PC for Pu(III) is derived from the second portion of the data set by fitting the Pu(IV)-PC from the first part of the data set. The critical assumption is that $\mathrm{Pu}(\mathrm{VI})$ and $\mathrm{Pu}(\mathrm{III})$ do not coexist in the solution at the same time. Additional details are described in the data treatment for Batch \#2. ${ }^{4}$ 


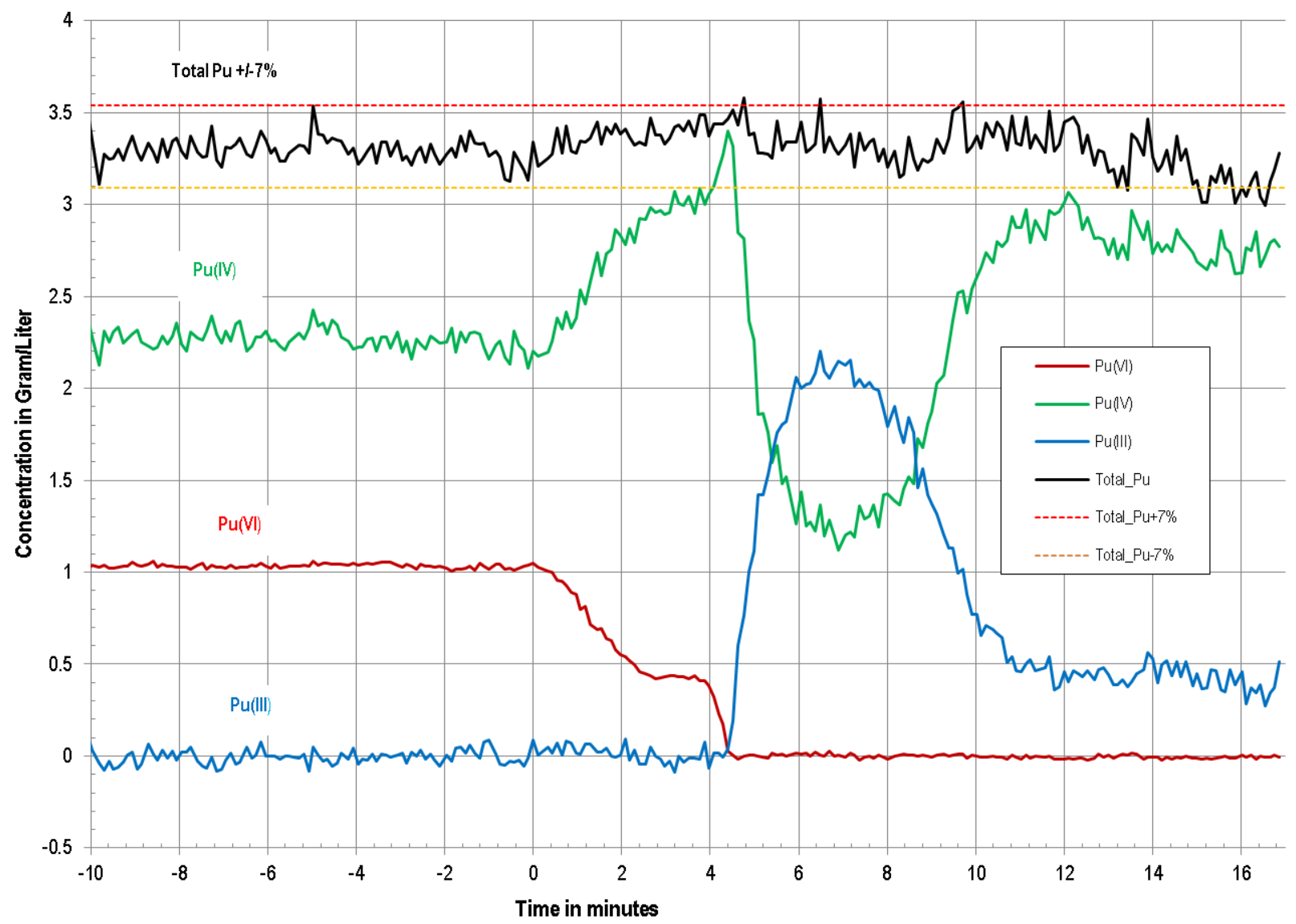

Figure 5. Pu(VI), Pu(IV) and Pu(III) Speciation during FS Adjustment of AFS-2 Batch 3 in Tank 12.2 on $9 / 18 / 13$.

Figure 5 shows the results from the PCR modeling and shows the calculated speciation over the course of the FS adjustment. The analysis shows the pre-treatment solution to be $\sim 30 \% \mathrm{Pu}(\mathrm{VI})$ and $70 \% \mathrm{Pu}(\mathrm{IV})$ compared with the previous analysis which found the solution when in was still in the 6.1D dissolver to be $39 \% \mathrm{Pu}(\mathrm{VI})$ and $61 \% \mathrm{Pu}(\mathrm{IV})$. Considering the issues with the observed $\mathrm{Pu}(\mathrm{IV})$ peak in the current dataset, these values are fair agreement.

\section{Discussion and Observations:}

The absorbance data appears noisier than we have seen before, especially in the short wavelength region of the spectra. Noise in the data has been observed in the past with the "at-line" spectrometer and is thought to be due in part to bubbles in the sampling system and averaging of good spectra with poor spectra. It may be possible to improve the quality of the data by rejecting poor spectra from the averaging process. Noise level may also be reduced by an adjustment in the integration time to raise the signal to noise ratio in the measurements. This noise level probably limits the precision of the results.

The $\mathrm{Pu}(\mathrm{IV})$ peak between $470 \mathrm{~nm}$ and $490 \mathrm{~nm}$ is lower in intensity and broader than we have seen in the past two batches. There is some evidence, seen in the second derivative data treatment that the peak is actually two closely spaced peaks, one near $476 \mathrm{~nm}$ and the other near $490 \mathrm{~nm}$. This may be due to formation of two types of $\mathrm{Pu}(\mathrm{IV})$-nitrate complexes co-existing in the intermediate nitric acid concentration found in this third batch. The Pu(IV) peak location from the first batch (higher acid) on July 11, 2013 is near $490 \mathrm{~nm}$, while the Pu(IV) peak location from the second batch (lower acid) on August 1, 2013 is near $476 \mathrm{~nm}$. It appears that the ratio of the two Pu(IV) species changes during the 
treatment, favoring the higher acid form at the beginning of the treatment, but the lower acid form by the end of the treatment. The dilution of the tank solution should be on the order of $1 \%$, so it is unclear that this effect could be significant. However the presence of two separate species of Pu(IV) would complicate the interpretation of the amount of $\mathrm{Pu}(\mathrm{IV})$ present and increase the quantitative uncertainty by unknown amounts. It is assumed that the amount of $\mathrm{Pu}(\mathrm{IV})$ can be estimated by the average of all $\mathrm{Pu}(\mathrm{IV})$ spectra. From data predicting total $\mathrm{Pu}$ as the sum of $[\mathrm{Pu}(\mathrm{IV})+\mathrm{Pu}(\mathrm{III})+\mathrm{Pu}(\mathrm{VI})]$ this assumption yields a 2 sigma standard deviation of $7 \%$, which can be used as an estimate of the uncertainty in $\mathrm{Pu}(\mathrm{IV}) . \mathrm{Pu}(\mathrm{VI})$ disappears in two steps (Figure 5) (from $\sim 0$ minutes to $\sim 2.5$ minutes and then again from $~ 3.7$ minutes to $\sim 4.4$ minutes). This may represent the initial addition of FS and the water flush (used to flush the residual FS in the transfer line into the tank) as two separate steps or it may simply reflect transient mixing behavior in either the tank or the sampling system. The uncertainties introduced by the interpretation $\mathrm{Pu}(\mathrm{IV})$ affect the uncertainty in the amount of $\mathrm{Pu}(\mathrm{VI})$ predicted at the beginning of the treatment, but not the conclusion that all $\mathrm{Pu}(\mathrm{VI})$ is consumed during the FS treatment. $\mathrm{Pu}(\mathrm{IV})$ grows in as $\mathrm{Pu}(\mathrm{VI})$ disappears, and reaches a maximum at $\sim 4.4$ minutes when $\mathrm{Pu}(\mathrm{VI})$ approaches zero.

$\mathrm{Pu}(\mathrm{III})$ grows in and $\mathrm{Pu}(\mathrm{IV})$ drops, after all $\mathrm{Pu}(\mathrm{VI})$ has disappeared, but reaches a maximum at $\sim 6.7$ minutes and then decreases (Figure 5). This sort of transient behavior was not observed previously but may be due to some sort of transient mixing behavior in either the tank or the sampling system. The system reaches steady-state after about 12 minutes. Based on the ultimate stable spectra (beyond 12 minutes) of $\mathrm{Pu}(\mathrm{IV})$ and $\mathrm{Pu}(\mathrm{III})$ it is believed that the amount of FS that was added was appropriate.

\section{Investigation on the Main Pu(IV) Peak at 475-486 nm:}

Spectral analysis of the 9/28 12.2 sample sent to SRNL confirmed both the wavelength and shape of the main $\mathrm{Pu}(\mathrm{IV})$ peak (Figure 6a) that the source of concern suggesting that this appearance is due to acid concentration in the sample. The H-Canyon sample $\operatorname{logs}^{6}$ were consulted for the history of the Batch 3.

Table 1. Analytical Results and Volume History for Batch 3 (7HD Pu-3).

\begin{tabular}{cccccccc}
\hline Tank & LIMS \# & Date & $\begin{array}{c}\text { Volume } \\
\text { lbs }\end{array}$ & L & $\begin{array}{c}\text { Pu } \\
\text { g/L }\end{array}$ & $\begin{array}{c}\text { Free } \mathrm{H}+ \\
\text { M }\end{array}$ & $\begin{array}{c}\text { Density } \\
\text { g/mL }\end{array}$ \\
\hline $6.1 \mathrm{D}$ & 200635766 & & 16305 & 5755 & 3.539 & 9.68 & 1.2863 \\
$6.1 \mathrm{D}$ & 200635767 & & 16294 & & 3.442 & 9.90 & 1.2854 \\
7.4 & 200636315 & $8 / 22 / 2013$ & 16451 & 5790 & 3.359 & 9.68 & 1.290 \\
7.4 & 200636316 & $8 / 22 / 2013$ & & 5790 & 3.384 & 9.68 & 1.290 \\
7.4 & 200637593 & $8 / 28 / 2013$ & 16416 & 5773 & 3.430 & 9.19 & 1.291 \\
7.4 & 200637593 & recheck & & & 3.373 & & \\
7.4 & 200637594 & $8 / 28 / 2013$ & & 5773 & 3.443 & 9.19 & 1.291 \\
7.4 & 200637594 & recheck & & & 3.379 & & \\
7.4 & 200637933 & $9 / 3 / 2013$ & 16296 & 5731 & 3.385 & 8.79 & 1.2909 \\
7.4 & 200637934 & $9 / 3 / 2013$ & & 5731 & 3.387 & 8.92 & 1.2909 \\
12.2 & Transfer 7.4 to 12.2 & $9 / 13 / 2013$ & 16805 & & & & \\
12.2 & 200638668 & $9 / 13 / 2013$ & 16774 & 5935 & 3.313 & 8.34 & 1.2831 \\
12.2 & 200638669 & $9 / 13 / 2013$ & & 5934 & 3.311 & 8.09 & 1.2834 \\
12.2 & FS addition & $9 / 18 / 2013$ & 17264 & 6107 & & & 11.2834 \\
12.2 & 200639981 & $9 / 28 / 2013$ & 16927 & 6002 & 3.356 & 8.54 & 1.2804 \\
12.2 & 200639982 & $9 / 28 / 2013$ & & 6004 & 3.335 & 8.42 & 1.2799 \\
\hline
\end{tabular}

\footnotetext{
${ }^{6}$ R. G. Brown, Personnal Communication, H-Canyon Engineering, Savannah River Nuclear Solutions, Aiken SC July-October 2013.
} 
SRNL-STI-2013-00694

Revision 0

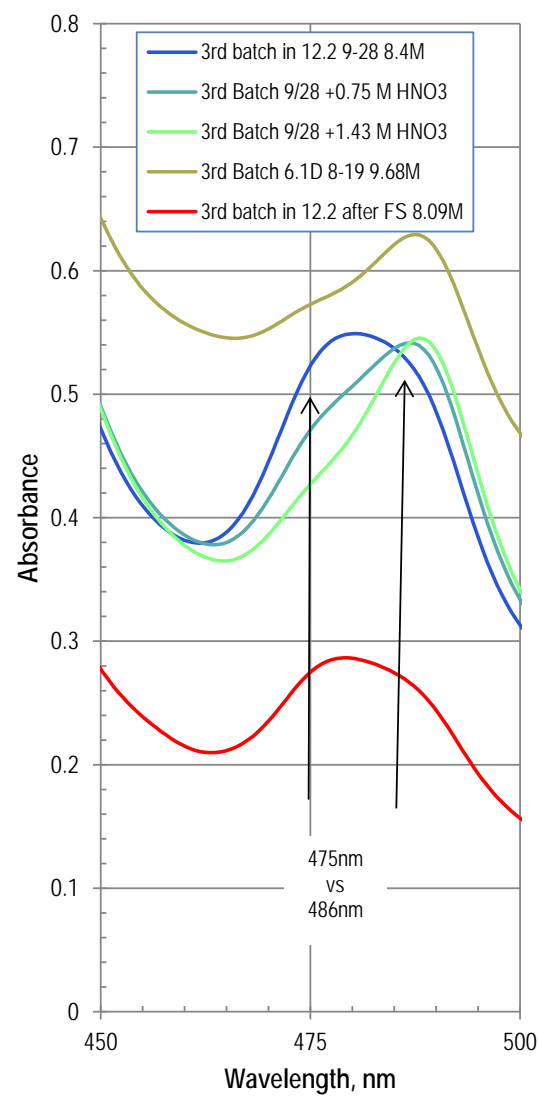

6a)

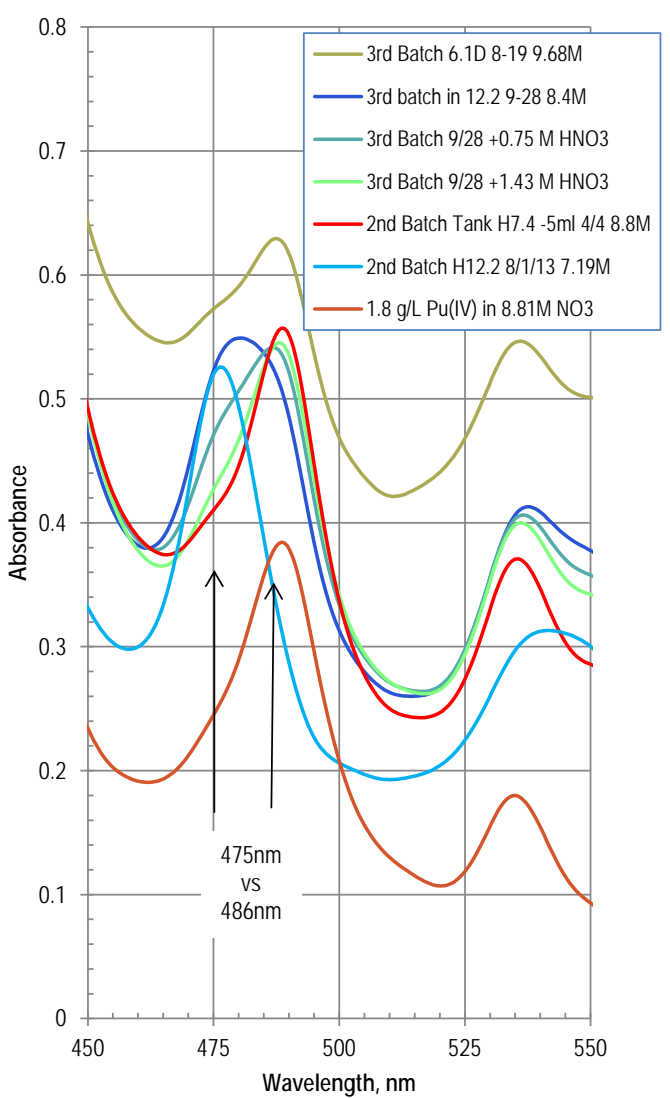

6b)

Figure 6. Shift in Main Pu(IV) Absorbance Peak: a) Shift in 9/28 Sample with the Addition of 0.75 and 1.42M $\mathrm{HNO}_{3}$, b) Comparison of Batch 2 and Batch 3 at Different Stages and Acid Concentrations.

solution and this is shown in Table 1 . When this solution was initially prepared and sampled for FS Treatment in the 6.1D dissolver, the $\mathrm{HNO}_{3}$ concentration was $\sim 9.68 \mathrm{M}$. Although the acid analyses of this solution reported to have standard error of $\sim 9.1 \%^{7}$, it appears that the acid concentration has fallen to 8.0-8.5M by the time that it was transferred to Tank 12.2 and the FS treatment performed. Figure $7 \mathrm{~b}$ shows spectra from Batches 2 and 3 compared to a reference spectrum prepared at $8.8 \mathrm{M}$ total nitrate. Figure $7 \mathrm{~b}$ shows the variation between a $475 \mathrm{~nm} \mathrm{Pu(IV)} \mathrm{peak} \mathrm{at} \mathrm{lower} \mathrm{nitrate} \mathrm{and} \mathrm{a} 486 \mathrm{~nm} \mathrm{Pu(IV)}$ peak at higher nitrate. At this time we are assuming that these changes depend on total nitrate rather than only $\mathrm{HNO}_{3}$ concentration. Confirmation of this assumption will be important in future work.

Marsh $^{8}$ performed a study that looked at the speciation of $\mathrm{Pu}(\mathrm{IV})$ complexes in this acid range and also observed this transition. Figure 7 is a graph in Marsh's report which shows significant spectral changes between 5 and $10 \mathrm{M} \mathrm{HNO}_{3}$. Figure 8 (also from Marsh's report) focuses on the main $\mathrm{Pu}(\mathrm{IV})$ peak where we have observed this shift in wavelength from 475 to $486 \mathrm{~nm}$. Much like in our observations, Marsh's spectra show that at $8 \mathrm{M} \mathrm{HNO}_{3}$, the main $\mathrm{Pu}(\mathrm{IV})$ peak is broadened and flattened in this acid region.

\footnotetext{
${ }^{7}$ C. B. Stoyle, “Analytical Uncertainty Parameters for Selected F/H Laboratory Methods” SRNL-L4600-2013-00043, Rev 0, Savannah River Nuclear Solutions, Aiken SC, April 5, 2013.

${ }^{8}$ S. F. Marsh, R. S. Day, D. K. Veirs, "Spectrophotomehic Investigation of the Pu(IV) Nitrate Complex Sorbed by Ion Exchange Resins”, LA-12070, Los Alamos National Laboratory, Los Alamo, NM, June 1991.
} 
SRNL-STI-2013-00694

Revision 0

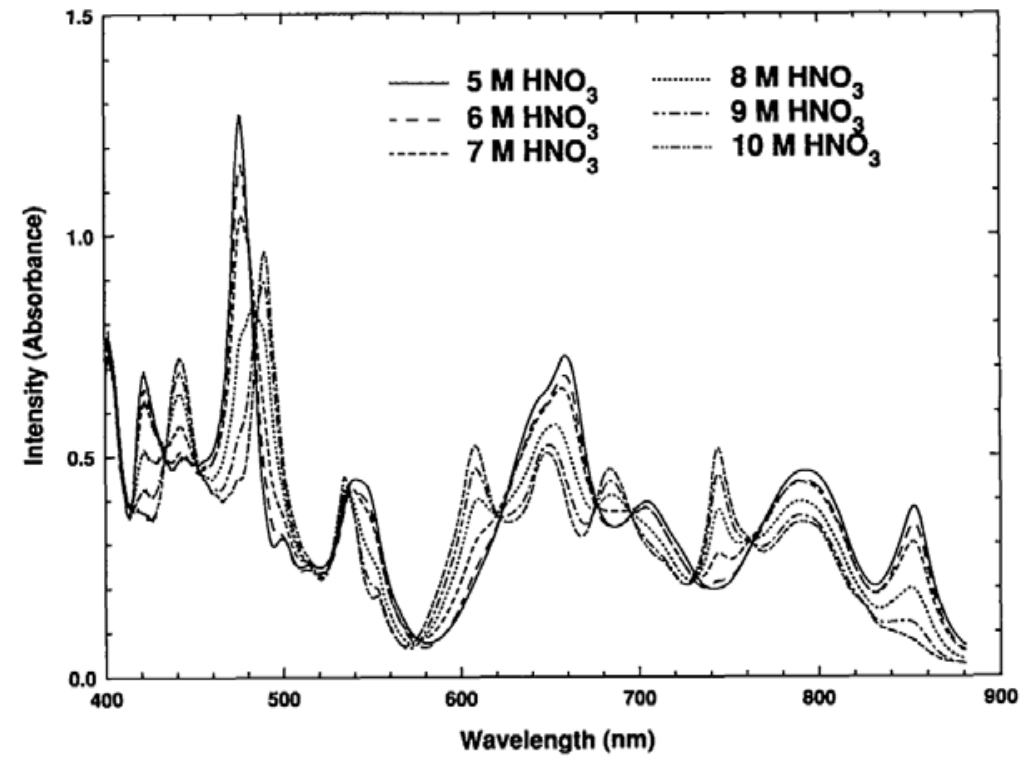

Figure 7. Effect of $\mathrm{HNO}_{3}$ Concentration on the Absorbance Spectrum of $\mathrm{Pu}(\mathrm{IV})$ between 5 and $10 \mathrm{M} \mathrm{HNO}_{3 .}{ }^{8}$

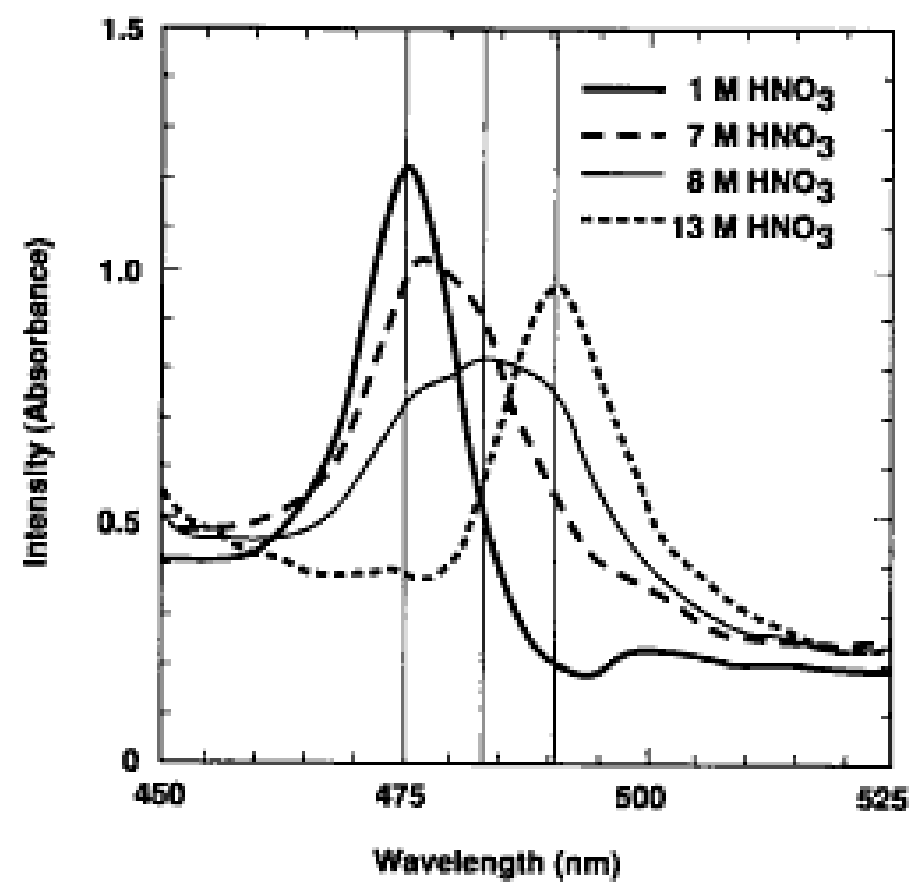

Figure 8. Shift in Main Pu(IV) Absorbance Peak between 1 and $13 \mathrm{M} \mathrm{HNO}_{3}{ }^{8}$

Due to the uncertainty in the measured acid concentration in the Batch 2 and 3 samples as well as the unknown uncertainty in the acid concentration in Marsh's work, we are not absolutely certain of the beginning and end of this transition region. However it is apparent that between 7 and $9 \mathrm{M} \mathrm{HNO}_{3}$, one should expect to see this shift occur. The lower sensitivity of the spectrophotometer to this short broad $\mathrm{Pu}(\mathrm{IV})$ peak likely increases the uncertainty of the valence analysis that we are using and it would be prudent to obtain more precise data on this transition as a function of nitrate concentration. It also may be 
helpful to modify the mathematical manipulation of the spectra to optimize the method sensitivity if the sample is in this acid concentration region.

\section{Conclusions and Recommendation:}

Despite the complications from $\mathrm{Pu}(\mathrm{IV})$ caused by acid concentration effects, we conclude that all $\mathrm{Pu}(\mathrm{VI})$ was consumed during the FS treatment, and that by the end of the treatment, about $85 \%$ was as $\mathrm{Pu}(\mathrm{IV})$ and about $15 \%$ was as $\mathrm{Pu}(\mathrm{III})$. Follow-up samples sent to SRNL showed no evidence of either Pu(VI) or $\mathrm{Pu}(\mathrm{III})$. Due to the possibility that we will have additional samples in this acid region in the future, we plan to obtain more precise spectra in the transition acid concentration region to improve the Pu valence analytical technique. Since the spectra evidence shows complete reduction of $\mathrm{Pu}(\mathrm{VI})$ we conclude that it is appropriate to proceed with processing of this the batch of feed solution for HB-Line including the complexation of the fluoride with aluminum nitrate. 


\section{Distribution:}

S. L. Marra, 773-A

T. B. Brown, 773-A

D. H. McGuire, 999-W

S. D. Fink, 773-A

C. C. Herman, 773-A

E. N. Hoffman, 999-W

F. M. Pennebaker, 773-42A

W. R. Wilmarth, 773-A

W. E. Harris, 704-2H

J. B. Schaade, 704-2H

P. B. Andrews, 704-2H

M. J. Lewczyk, 221-H

K. P. Burrows, 704-2H

K. J. Gallahue, 221-H

J. E. Therrell, 704-2H

S. L. Garrison, 704-2H

J. E. Elkourie, 704-2H
K. J. Usher, 704-2H

J. M. Jordan, 704-2H

R. H. Smith, 704-2H

W. H. Clifton, 704-2H

S. L. Hudlow, 221-H

R. G. Brown, 221-H

J. L. Bodkin, 22-1H

E. A. Kyser, 773-A

T. S. Rudisill, 773-A

T. C. Shehee, 773-A

K. M. L. Taylor-Pashow, 773-A

R. A. Pierce, 773-A

J. M. Duffey, 773-A

M. C. Thompson, 773-A

P. E. O’Rourke, 773-A

R. J. Lascola, 773-41A

L. T. Sexton, 773-42A

Records Administration (EDWS) 